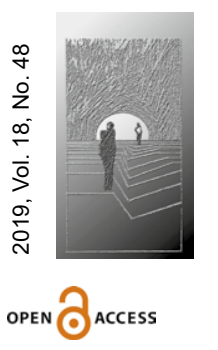

Anna Maria Pawiak

http://orcid.org/0000-0002-0104-190X Uniwersytet Kazimierza Wielkiego w Bydgoszczy Instytut Komunikacji Społecznej i Mediów pawiak@ukw.edu.pl

DOI: 10.35765/HW.2019.1848.01

\title{
Wybrane przestrzenie życia rodzinnego w kontekście nowomedialnym
}

\section{STRESZCZENIE}

CEL NAUKOWY: Celem jest zaprezentowanie potencjalnych oddziaływań nowych mediów na życie współczesnej rodziny. Jednym z czynników decydujących o tym, czy będzie to pozytywne, czy negatywne oddziaływanie, jest poziom kultury informatyczno-informacyjnej jej członków, w tym przede wszystkim rodziców.

PROBLEM I METODY BADAWCZE: Problem badawczy prezentowanego artykułu dotyczy poszukiwania odpowiedzi na pytania: Jak nowe media oddziałują na funkcjonowanie współczesnej rodziny? Jak ważnym wzorcem dla dziecka są rodzice kształtujący odpowiedzialne postawy aktywnego uczestnictwa w społeczeństwie informacyjnym?

PROCES WYWODU: W artykule przytoczyłam nowe pojęcie świata hybrydy jako przenikającego się świata realnego i wirtualnego. Zwróciłam uwagę na znaczenie kultury informatycznej i informacyjnej rodziców. Ukazałam, jakie są powody i skutki tego, że dzieci ulegają tak głębokiej immersji.

WYNIKI ANALIZY NAUKOWEJ: Dzięki nowym mediom współczesna rodzina funkcjonuje w świecie hybrydowym, który jest konwergencją świata realnego i wirtualnego. Nowe media wbrew pozorom nie przynoszą tylko jednego rodzaju efektu, tego negatywnego, o którym mówi się najczęściej. To, czy staną się one bardziej ciężarem, czy błogosławieństwem, zależy od człowieka.

WNIOSKI, INNOWACJE, REKOMENDACJE: Z rozważań płynie wniosek wskazujący na konieczność uświadamiania rodzicom, że nowe media nie muszą mieć tylko i wyłącznie negatywnego wpływu na budowanie więzi rodzinnych, ale mogą się stać spoiwem wspólnie i ciekawie spędzanego czasu. Należy również uzmysłowić rodzicom, jakie następstwa niesie za sobą zjawisko sharentingu (ekshibicjonizmu rodzicielskiego), troll parentingu czy public shamingu (kid shaming). Wnioskuję o konieczność przeprowadzenia badań w celu ustalenia, czym kierują się rodzice, jaka jest ich motywacja lub zakres działań związanych z ujawnianiem informacji na temat swoich dzieci.

\section{$\rightarrow$ SŁOWA KLUCZOWE: RODZINA, NOWE MEDIA, KULTURA} INFORMATYCZNO-INFORMACYJNA 


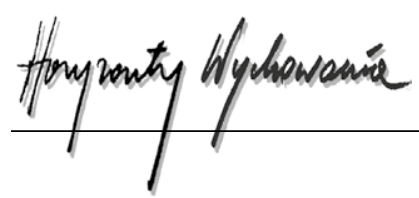

ABSTRACT

A Contemporary Family in the Context of the New Media

RESEARCH OBJECTIVE: The objective is to present both negative and positive examples of influence of the new media on the life of a contemporary family. The parents' IT and information culture is decisive for the new media impact type and extent.

THE RESEARCH PROBLEM AND METHODS: How do the new media influence the functioning of a modern family, how important for children are parents as role models shaping their attitudes of active participation in the information society, and what fashionable trends do the parents follow when publishing information concerning their children in the new media.

THE PROCESS OF ARGUMENTATION: The article makes use of a new term: the hybrid world, i.e. the real and virtual worlds permeating each other. It focuses on the importance of parents' IT and information culture for creating the modern and safe world for the contemporary family to function in. The author presents reasons for children to become deeply immersed in the media as well as chosen negative implications of the new media impact.

RESEARCH RESULTS: The new media have become an inherent element of a family functioning in the hybrid world of today. There is no escape from technological innovations, and they do not generate only the most often discussed and publicised negative effects. The influence of the new media on a family depends mainly on how reasonably the technological tools are used by particular family members.

CONCLUSIONS, INNOVATIONS, AND RECOMMENDATIONS: Basing on the above argument it may be concluded that it is necessary to make parents aware of the fact that the new media do not have only a negative effect on family bonds. They might also contribute to building relations by creating opportunities of spending time together in an interesting way. Parents should also be conscious and informed about the consequences of sharenting, parental trolling or public shaming.

\section{$\rightarrow$ KEYWORDS: FAMILY, NEW MEDIA, IT AND INFORMATION CULTURE}

\section{Wstęp}

Rodzina jest podstawową komórką społeczeństwa, która podlega nieustannym zmianom na skutek oddziaływania różnych czynników zewnętrznych. Jeden z nich to ciągły rozwój nowych mediów. Niniejszy artykuł poświęcony został refleksji nad znaczeniem nowych mediów dla relacji w rodzinie, której przyszło funkcjonować w nowym świecie hybrydowym. Członkowie współczesnej rodziny, zarówno dzieci, jak i ich rodzice, ulegają zjawisku częściowej lub całkowitej immersji, czyli silnemu „zanurzeniu” w świat nowych mediów. W świecie dziecka zdominowanym przez media niezwykle ważną rolę mają do odegrania rodzice. 
Rozwój środków masowej komunikacji wytycza kolejne zadanie, przed którym stają współcześni rodzice. Wiąże się ono z koniecznością ciągłego doskonalenia się w zakresie nie tylko zdobywania umiejętności posługiwania się nowymi technologiami, lecz także rozwijania umiejętności filtrowania informacji, jakie napływają do ich dzieci i całego systemu rodzinnego (Dec, Dereń i Grabek, 2014, s. 180).

W dużej mierze odpowiedzialność za sposób korzystania przez dzieci z mediów z całą rozciągłością negatywnych i pozytywnych skutków ponoszą rodzice. Rolą ich jest podejmowanie decyzji, na jakim etapie życia dziecko powinno rozpocząć swą przygodę z dostępnymi mediami mobilnymi i w jakim zakresie czasowym powinno korzystać z szeroko dostępnego wachlarza tych mediów w ciągu dnia. Pamiętać należy, że wirtualny świat nowych mediów, w którym wychowywali się rodzice, różni się znacznie od dzisiejszego, bardziej skomplikowanego, wielowymiarowego i drapieżnego świata, w którym przyszło wychowywać się obecnemu pokoleniu.

\section{Implikacje nowych mediów dla współczesnej rodziny}

Jak słusznie zauważa Katarzyna Sobczak, we współczesnym świecie nie sposób określić wyraźnej granicy między „wirtualem” a „realem”. To, co zwykło się do tej pory nazywać rzeczywistością, jak i to, co określano mianem „wirtualu”, stanowi obecnie w koncepcji świata cyberrealnego jeden wspólny i ten sam świat (Sobczak, 2014, s. 29). Połączenie świata wirtualnego i realnego stało się rzeczą nieuniknioną. Janusz Morbitzer (2016) wskazuje na powstanie świata hybrydy, będącego konwergencją świata realnego i wirtualnego, bez precyzyjnego wskazywania granic. Wszyscy członkowie współczesnej rodziny stali się mimowolnie obywatelami tego świata, gdyż zarówno rzeczywistość, jak i „wirtual”, będąc wytworami człowieka, stanowią zaplecze i źródło jego kultury. Przenikanie się tych światów bez wątpienia wpływa na jednostki, kształtując je według zasad, którymi się owa hybryda rządzi, przynosząc namacalne skutki w życiu człowieka. Sam fakt korzystania na co dzień z nowych mediów to zbyt mało. Zdaniem Tomasza Gobana-Klasa (2005), umiejętność posługiwania się dostępnymi mediami polega nie tylko na towarzyszeniu im, ale też na dostrzeganiu ich znaczenia i roli w kształtowaniu nowoczesnego i bezpiecznego społeczeństwa, w tym również bezpiecznej rodziny.

Kultura rodziny, którą tworzą normy, wartości, wzory zachowań w środowisku domowo-rodzinnym, jest odpowiedzialna za żyzność „gleby dla rozwoju człowieka, a szczególnie dziecka, dla którego rodzina i dom stanowią podstawową grupę w kształtowaniu jego tożsamości i stosunku do świata" (Doniec, 2017, s. 219), w tym również świata hybrydowego. Znaczenie przygotowania rodziców i dzieci do korzystania z mediów wydaje się „tak oczywiste jak przygotowywanie do życia rodzinnego, gospodarczego czy politycznego. Dostrzegalna jest rozbieżność: media rozwijają się niezwykle dynamicznie, ale większość użytkowników pozostaje na poziomie swoistego analfabetyzmu" (Pomiankowska-Wronka, 2016, s. 61). Często dużym problemem jest różnica poziomu odpowiedniej wiedzy rodziców w porównaniu z wiedzą, jaką posiadają już ich dzieci. 


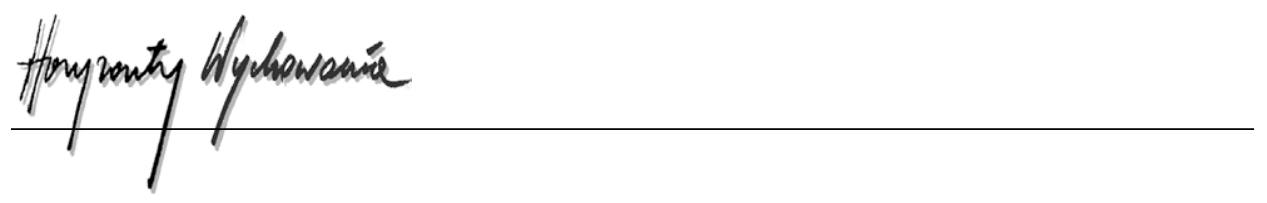

Kanadyjski badacz Internetu Don Tapscott (2010, s. 38) ostrzega: „Uwaga, nadchodzi zmiana pokoleń. Już dziś młodzież uczy się, bawi, komunikuje, pracuje i tworzy społeczności w zupełnie inny sposób niż ich rodzice. To oni są siłą napędową przemian społecznych". Jeszcze do niedawna to rodzice byli niekwestionowanym autorytetem dla dzieci. Dzisiaj dla dzieci nowe technologie są czymś naturalnym, ponieważ towarzyszą im od najmłodszych lat. Poza migracją zarobkową, konfuzją wartości społecznych, ateizacją, preferowaniem konsumpcyjnego stylu życia i lekceważeniem tradycji rodzinnych system kulturowy współczesnej rodziny zaburzony jest przez współczesne technologie. Rodzina stanowi podstawowe środowisko, w którym dziecko wzrasta fizycznie, wrasta w społeczeństwo, a także jest wprowadzane w kulturę. Trudno być obojętnym na kwestie oddziaływania nowych mediów na rodzinę, kształtowanie kultury informatyczno-informacyjnej rodziców i dziecka. Przejawem posiadania kultury informatycznej są umiejętności doboru właściwych narzędzi informatyki do określonych zadań, przyswojenie i prawidłowa interpretacja podstawowych terminów i pojęć informatyki w zakresie użytkownika oraz orientacja w nowych tendencjach i technologiach informatycznych. Niezbędne są również umiejętności uczenia się i znajdowania źródeł informacji o nowych możliwościach wykorzystywania komputerów, posługiwania się podstawowymi środkami technicznymi, jak np. klawiatura, drukarka, mysz. Kultura informatyczna członków rodziny to także nawyki prawidłowego obchodzenia się ze zbiorami danych (problem bezpieczeństwa informacji, a także przekonanie, że sprzęt i oprogramowanie muszą być traktowane łącznie jako jedno informatyczne narzędzie; Cieciura 2012, s. 252). Natomiast

\begin{abstract}
kultura informacyjna jest określonym sposobem korzystania z informacji, ukształtowanym przez świadomość informacyjną użytkownika, wartości, które uznaje, postawy, które reprezentuje, motywy, które nim kierują. Winna być pożądaną częścią nie tylko kultury pracy, kultury technicznej, ale też kultury zdrowotnej, politycznej, osobistej, kultury rodziny (na którą składa się między innymi przygotowanie do świadomego korzystania z nowych mediów i uczestniczenia w życiu społeczeństwa hybrydowego). Kultura informacyjna określa bowiem, jakie zachowania informacyjne są z punktu widzenia etyki pożądane i pozytywnie oceniane, jakie wzory tych zachowań włączyć do kodeksu człowieka o wysokiej kulturze, jakie postawy względem informacji powinny charakteryzować jej użytkowników, jakie reprezentują oni wartości, jaki powinni osiągnąć poziom świadomości informacyjnej (Furmanek, 2012, s. 22).
\end{abstract}

Wpływ rodziców na kształtowanie kultury informatyczno-informacyjnej powinien rozpocząć się w momencie pojawienia się w domu rodzinnym nowych mediów. Mobilne media to często wymarzony prezent dziecka. Zapytane, co chce dostać w prezencie (na urodziny, pod choinkę, z okazji Pierwszej Komunii Świętej), najczęściej odpowiada: iPada, tablet, laptopa albo smartfona. Według wyników badań przeprowadzanych co roku od 2010 r. przez Digital Diaries, dzieci już w wieku 2-5 lat uczą się obsługi komputera czy korzystania z mediów mobilnych. W Polsce ponad $40 \%$ dzieci przed 2. rokiem życia korzysta już z urządzeń mobilnych, a blisko 30\% używa ich codziennie (Waluś, 2016). Często media mobilne traktowane są przez rodziców jako zabawka, sposób uciszenia dziecka, odwrócenia jego uwagi, dzięki czemu nie wymaga ono szczególnej opieki 
w danym momencie. Przeprowadzone w 25 państwach UE badania wykazały, że dzieci pierwszy kontakt z Internetem mają między 7. a 11. rokiem życia. W Polsce przeciętny wiek pierwszego logowania do sieci to 9 lat. W porównaniu z Europą (31\%) więcej dzieci w Polsce (34\%) łączy się z Internetem za pomocą mobilnych mediów. Niepokojące jest jednak to, że polskie dzieci częściej łączą się z Internetem poza możliwościami kontroli rodzicielskiej: więcej z nich (52\%) niż średnio w Europie (35\%) łączy się z Internetem ze swojego własnego komputera. Owszem, według badań przeprowadzonych przez Lucynę Kirwil

kompetencje dzieci w Internecie rosną wraz z wiekiem, ale wciąż bardzo duży odsetek (od ponad jednej trzeciej do dwóch trzecich) stanowią dzieci, które nie nabyły umiejętności niezbędnych do bezpiecznego korzystania z Internetu. Te dzieci są najbardziej narażone na ryzyko rozmaitych zagrożeń w Internecie - mają poczucie, że mogą się w nim swobodnie poruszać, ale nie posiadają instrumentów gwarantujących im bezpieczeństwo (2011, s. 14).

Dziecko, które staje się szczęśliwym posiadaczem mobilnych mediów, powinno wiedzieć, jakim narzędziem (zabawką) dysponuje.

Jakie są możliwości techniczne takiego urządzenia, jakie są opcje i udogodnienia. Ale jednocześnie dziecko od najmłodszych lat musi wiedzieć co może, czego raczej nie powinno i czego zdecydowanie mu nie wolno. Musi także wiedzieć, że istnieje coś takiego jak etyka i kultura w Sieci, że i tutaj panują „czarodziejskie słowa” (m.in.: proszę, dziękuję, przepraszam). Z wychowawczego punktu widzenia taki „instruktarz" wydaje się niezbędny. Niestety, nie wszyscy dorośli mają taką wiedzę i umiejętności oraz widzą potrzebę uczenia dziecka czegoś, do czego nie przywiązują wagi i czego sami nie stosują (Kwiasowski, 2016, s. 183).

Zachowanie dziecka w świecie hybrydowym bez wpojenia mu szacunku dla drugiego człowieka, bez podstaw kultury osobistej, często skutkuje zjawiskami wpisującymi się w pojęcie zagrożenia. Zachętą do takiego zachowania jest pozorna anonimowość w sieci. Sprzyja to nieprzestrzeganiu praw drugiego człowieka, braku poszanowania jego godności, wulgaryzmom, emanowaniu agresją, nienawiścią, a często po prostu jest wynikiem braku odpowiedzialności za swe czyny. Należy być świadomym, że dzieci naśladują zachowania obserwowane u rodziców. Niestety dziecko, które nie ma możliwości znalezienia wzorca zachowań u rodziców, zaczyna go poszukiwać gdzie indziej, wyobcowując się z rodziny. Przyswaja nowy styl zachowania, dokładnie analizuje i wykorzystuje uwagi rówieśników na temat swojego postępowania, by poczuć pełniejsze uczestnictwo w grupie i jej akceptację. Często jest to grupa znajomych poznanych w cyberprzestrzeni, do której rodzice nie mają dostępu, a nie wszyscy znajomi są uczciwymi rozmówcami czy rówieśnikami.

Warto się zastanowić, co jest w dzisiejszych czasach przyczyną tak dużej immersji dziecka, przy jednoczesnym oddaleniu się od rodziny, dlaczego rodzice nie potrafią rozpoznać wczesnego etapu zatracania się dziecka w świecie nowych mediów. Częstym powodem jest po prostu 


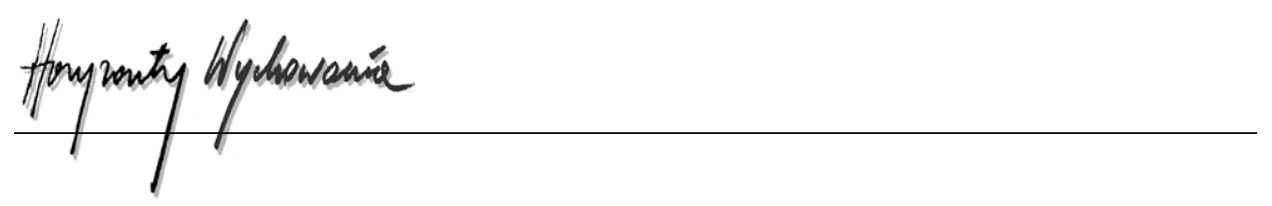

nuda, stres, odrzucenie przez środowisko rówieśnicze czy niskie poczucie własnej wartości. Moment, kiedy dziecku brakuje ciekawszych form spędzania wolnego czasu, ucieka ono w rzeczywistość medialną, albo próbuje skompensować brak realnych kontaktów ze znajomymi na te w środowisku wirtualnym. Fakt ten powinien być dla opiekuna sygnałem, by podjąć z takim młodym człowiekiem rozmowę (Ogonowska, 2015, s. 168-169).

Media mobilne coraz częściej traktowane są jak nowy uczestnik w rodzinie. Dźwięk komórki staje się zmorą nie tylko spotkań publicznych, miejsc publicznych, ale niestety również spotkań rodzinnych. Nowe media zastępują normalną, czasem trudną i wymagającą rozmowę. Łatwiej przekazać SMS-em treść dotyczącą trudnej, osobistej sprawy, niż przeprowadzić odważnie szczerą rozmowę twarzą w twarz. Może to świadczyć o niewystarczających umiejętnościach komunikowania się z drugim człowiekiem, trudnościach w stawianiu czoła niełatwym sytuacjom lub słabej więzi rodzinnej, braku zaufania czy zrozumienia ze strony rodziców. Niewątpliwie wpływa to bardzo niekorzystnie na relacje między osobami tworzącymi rodzinę (Milewski, 2006). Dzieci spędzające dużo czasu w cyberprzestrzeni wtapiają się w sieć, stając się jej elementem - obok narzędzi technologicznych i obok innych ludzi, coraz bardziej oddalając się od drugiego człowieka, od rodziców, rodzeństwa, dziadków. Do tej pory uczestnicy funkcjonujący równolegle w rzeczywistości wirtualnej i realnej przenosili pewne nawyki, zachowania z jednego świata do drugiego. Dziś wiadomo, że nowe normy moralne, obyczaje, nowe wartości są wynikiem hybrydowego świata. Nie zmieniło się niestety jedno - brakuje czasu na spotkania i budowanie głębszych więzi w rodzinie. Potwierdzili to w swym eksperymencie naukowcy z Carnegie Mellon University prowadzący badania w okolicach Pittsburgha (Wallace, 2001). Stwierdzili, że wraz ze wzrostem ilości czasu spędzonego w sieci przez dzieci i młodzież słabnie kontakt z rodziną i przyjaciółmi. Anna Słysz i Beata Arcimowicz (2009, s. 112) na podstawie wyników otrzymanych z badań wskazują jednak na możliwość wykorzystania pasji dziecka i współuczestniczenia z nim w korzystaniu z nowych mediów. Może to się przyczynić do modelowania pożądanych zachowań dzieci w sieci, czyli zachowań bezpiecznych, zgodnych ze standardami etycznymi i zdrowotnymi. Spędzanie wspólnie czasu z wykorzystaniem mediów aktywuje współdziałanie polegające $\mathrm{np}$. na poszukiwaniu ciekawych informacji, zabawie i grach edukacyjnych. Niezwykle ważnym efektem dla rodzica będzie lepsza orientacja w tym, co dziecko robi przy komputerze, w Internecie, poznanie jego znajomych, zainteresowań i upodobań. Biorąc pod uwagę to, z jakich nowych mediów korzystamy i w jakim celu, nie muszą mieć one tylko i wyłącznie negatywnego oddziaływania na rodzinę. Świadczą o tym najnowsze

wyniki badań Samsung Techonomic Index przeprowadzonych we współpracy z Ipsos Mori wśród mieszkańców pięciu europejskich krajów, które w dokładny sposób pokazują wpływ nowoczesnych technologii na relacje rodzinne. Pomimo wciąż przyspieszającego tempa życia i wzrastającej liczby rodzin, których członkowie żyją w różnych miastach, relacje z najbliższymi oceniane są coraz lepiej. Prawie dwie trzecie respondentów (64\%) twierdzi, że za sprawą technologii (m.in. dzięki smartfonom, serwisom społecznościowym czy poczcie elektronicznej) więzi w ich rodzinach są silniejsze. Nowoczesna technologia mobilna sprawia, że ludzie częściej rozmawiają z najbliższymi krewnymi. Dotyczy to zwłaszcza rodziców, 
z którymi dorośli ankietowani rozmawiają co najmniej raz dziennie. Nowoczesne urządzenia pomagają sprostać wyzwaniom związanym z funkcjonowaniem w realiach współczesnego świata, jak życie w rozłące z najbliższymi lub praca po godzinach (Waluś, 2016, s. 46).

\section{Mobilne media}

dają szansę porozumiewania się o każdej porze dnia i niemalże w każdym miejscu na świecie, co jest szczególnie przydatne w przypadku rodzin emigracyjnych. Dużym walorem i zarazem wadą Sieci jest nieograniczony dostęp do informacji - w przypadku odbiorcy o niewykształconych kompetencjach medialnych selekcja informacji ważnych od tych błahych może okazać się zbyt trudna. Istotne jest, aby rodzice udowodnili dzieciom konieczność nabywania kompetencji w zakresie analizy i interpretacji mediów. Internet jest środkiem przekazu, od którego można uzależnić się w szybkim tempie. Dotyczy to zarówno dzieci, jak i rodziców. Kontakty online nie powinny zastępować tych face-to-face. Kluczowy w tym przypadku wydaje się również dotyk, który w wychowaniu odgrywa niezwykle ważną rolę. Przemoc w Sieci jest problemem niezwykle rozległym: molestowanie, zastraszanie, wyśmiewanie to tylko niektóre z problemów wirtualnego świata, których skutki przenoszą się do realnego życia. Fundamentem rodziny powinno być zaufanie, wsparcie, rozmowa i poszanowanie godności drugiego człowieka, bez tych wartości świat rodziny rozpada się (Pomianowska-Wronka, 2016, s. 64).

Zaskakującym zjawiskiem związanym z nowymi mediami i ich oddziaływaniem na relacje w rodzinie jest bezrefleksyjne publikowanie przez rodziców zdjęć swoich dzieci w sieci. Rodzice nie są najwyraźniej świadomymi tego, że wirtualni tubylcy odbierają wszystko to, co zostanie im pokazane, przesłane, opublikowane, i ten materiał staje się dla nich pożywką do bezlitosnej krytyki bohaterów zamieszczonych materiałów. Zjawisko to określane jest potocznie ekshibicjonizmem rodzicielskim lub terminem sharentingu i dotyczy dzielenia się online przez wielu rodziców szczegółami z życia swojego dziecka (Steinberg, 2017). Jak słusznie zauważył Phoebe Maltz Bovy (2013), aby mówić o sharentingu, należy spełnić dwa kryteria. Po pierwsze, niezbędna jest obecność masowej publiczności, po drugie zaś możliwość identyfikacji dziecka (2013). W związku z tym w rzeczywistości sharenting nie dotyczy ujawniania zdjęć, filmów itp. w gronie rodziny lub przyjaciół. Udostępnianie nie dotyczy również anonimowej publikacji materiałów na temat dziecka w Internecie, ponieważ w tym przypadku rozpoznanie dziecka jest niemożliwe. Nie ma jednak wątpliwości, że rodzice w ten sposób naruszają prawo do prywatności swoich dzieci. Może je to narazić na niebezpieczeństwo w teraźniejszości lub w przyszłości. Rodzice nie są w stanie przewidzieć konsekwencji tego rodzaju swojej aktywności w nowych mediach.

Być może należałoby przeprowadzić badania w celu ustalenia, czym kierują się rodzice, jaka jest ich motywacja lub zakres działań związanych z ujawnianiem informacji na temat swoich dzieci. Podanie do wiadomości publicznej przez rodziców wielu szczegółowych informacji o swoich dzieciach w formacie zdjęć, filmów lub postów za pośrednictwem mediów społecznościowych niewątpliwie narusza prywatność dzieci i może również negatywnie wpływać na kształtowanie tożsamości dziecka, pozbawiając je możliwości podjęcia decyzji co do materiałów, którymi chciałoby się podzielić z tak szeroką 


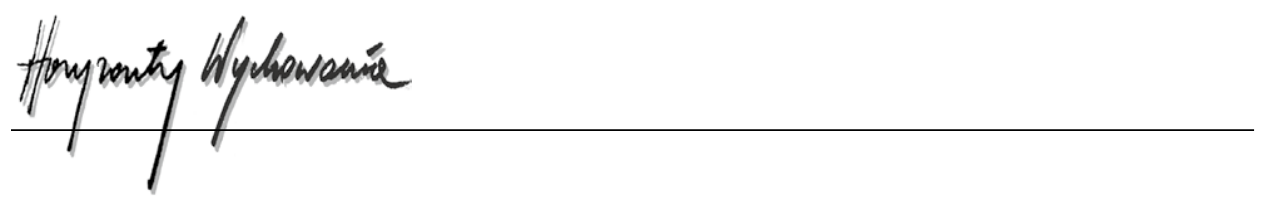

widownią online. Tożsamość dziecka powinna być jego osobistą, refleksyjną aktywnością. Jak stwierdza Giddens, ,jesteśmy nie tym, czym jesteśmy, ale tym, co z siebie zrobimy" (2001, s. 102). Niestety w tej sytuacji tożsamość dziecka może zostać zaburzona przez bezmyślne działania rodziców wykorzystujących nowe media w celu niejednokrotnie ośmieszenia dziecka, ukarania, bawienia się wręcz jego kosztem. Jak zauważa Łukasz Wojtasik,

przenoszenie do sieci relacji rodzic - dziecko, znajdującej się dotychczas w sferze prywatności, zapewne nie wpływa pozytywnie na atmosferę zaufania panującą w rodzinnym domu. Badania przeprowadzone na grupie europejskich matek pokazują, że $73 \%$ z nich opublikowało zdjęcia swojego dziecka zanim ukończyło ono drugi rok życia, a ponad $20 \%$ rodziców publikuje w Internecie zapis USG z okresu przed narodzinami potomka (cyt. za Gregorczyk, 2016, s. 192).

Rodzice zakładają dzieciom również profile w serwisach społecznościowych, zamieszczając w nich fotografie i informacje na ich temat. Niewyobrażalne jest publikowanie zdjęć dzieci w bieliźnie lub nago, do czego przyznaje się w Polsce co czwarty rodzic dziecka do 10. roku życia.

Zdjęcia czy filmy, które dla rodzica są z pozoru niewinne, mogą narazić dziecko na kpiny i żarty ze strony kolegów, a w przyszłości współpracowników czy znajomych. Kompromitujące zdjęcie może być w przyszłości wykorzystane, by zdyskredytować kogoś w jego środowisku zawodowym czy prywatnym. Powinno to zachęcić każdego rodzica do refleksji, które informacje mogą krążyć w sieci, a które powinny pozostać w sferze prywatnych relacji z dzieckiem (Gregorczyk, 2016, s. 192).

Niestety rzeczywistość pokazuje, że rodzice dzielą się treściami, które ośmieszają i kompromitują ich dzieci, pokazują trudne dla nich momenty życia. Jest to tzw. troll parenting (Majak, 2013), czyli publikowanie wizerunku dziecka w komicznym kontekście. Czasami są to rzeczywiste sytuacje, które przytrafiły się dziecku, niestety zdarzają się również te specjalnie aranżowane. Bardzo negatywnie na zaufanie w rodzinie wpływają sytuacje, kiedy rodzice udostępniają zdjęcia lub filmy mające na celu publiczne ukaranie jakiegoś zachowania, od którego należy dziecko odzwyczaić lub sprawić, aby nigdy nie zachowało się w taki sam sposób. Dużym echem odbiło się w mediach wydarzenie, do którego doszło w Portugalii w 2016 r. W Internecie zamieszczony został film, na którym widać, jak zdenerwowana matka przy pomocy maszynki goli swojej córce głowę, pozbawiając ją długich, kręconych włosów. Dziewczyna płacze i niemal zwija się z bólu, jednak matka nie ustępuje i dalej karci swoją córkę za zachowanie, o którym dowiedziała się wcześniej. Chodziło o to, że córka naśmiewała się z koleżanki ze szkoły, która straciła włosy w wyniku choroby nowotworowej. Matka w ten sposób zdecydowała się ukarać dziewczynę, dając jej nie tylko bardzo bolesną nauczkę na przyszłość, ale przede wszystkim ośmieszając publicznie. Tak nieodpowiedzialne i nieprzemyślane wykorzystanie nowych mediów do ukarania córki na pewno nie jest dobrą metodą wychowawczą, która przyniesie pozytywne skutki w przyszłości. Będzie to miało niebagatelny 
wpływ na przyszłe relacje matki i córki (https://archiwum.radiozet.pl/Wiadomosci/Swiat/ Portugalia-matka-ogolila-corce-glowe-bo-smiala-sie-z-chorej-na-raka-00029403).

Spędzanie czasu z dziećmi to jedyna szansa budowania i utrzymywania silnych fundamentów życia rodzinnego. Niestety, jak podkreśla Jadwiga Izdebska,

\begin{abstract}
większość polskich rodzin wieczory lub popołudnia w dni robocze i świąteczne spędza przed ekranem telewizora lub komputera. Takie zachowania w konsekwencji doprowadzają do osłabienia więzi rodzinnych oraz do jej dezintegracji. Obserwuje się, że wspólne spędzanie czasu ogranicza się jedynie do ,,bycia” ze sobą fizycznie - w milczeniu, ale nie wspólnie. W związku z tym mass media w drastyczny sposób ograniczają rodzinne rozmowy. Niepokojącym jest także, że media zastępują rodziców i opiekunów w pełnieniu przez nich funkcji opiekuńczo-wychowawczych. Media masowe zaczynają w coraz większym stopniu pełnić rolę elektronicznej niańki i pokazują dzieciom, jak oceniać czy postępować, kreując ogólny świat wartości, przez co rodzice są uwolnieni od organizowania dziecku czasu poza domem, wspólnych wyjazdów czy po prostu tradycyjnych spotkań z najbliższymi. Wielogodzinne i codzienne spędzanie czasu na obcowaniu z mediami prowadzi do zaburzeń w życiu rodzinnym, ograniczenia czasu na inne ważne obowiązki domowe, czy rezygnacji z wartościowych i potrzebnych w rozwoju życia czynności, jak choćby skrócenie czasu lub całkowite wyeliminowanie zabaw z rówieśnikami, zaprzestanie czytania książek, chodzenia do teatru, filharmonii, słuchania radia (cyt. za Waluś, 2019, s. 145).
\end{abstract}

Nie ma jednoznacznej odpowiedzi na pytanie, czy nowe media mają dobre, czy złe oddziaływanie na rodzinę i panujące w niej relacje. Stawianie w ten sposób pytania wydaje się wręcz bezzasadne. Korzystając z nowych mediów, warto przypomnieć sobie słowa Neila Postmana (1992, s. 16): „błędem jest sądzić, że jakakolwiek innowacja technologiczna przynosi tylko jednego rodzaju efekty. Każda technologia jest zarazem ciężarem i błogosławieństwem; nie albo-albo, lecz tym i tym jednocześnie".

\title{
Zakończenie
}

Nowe media wyjątkowo głęboko przeniknęły do życia społecznego, w tym wspólnoty życia rodzinnego. Obserwacja codzienności pokazuje, jak silne jest ich oddziaływanie. Pokonują bariery wiekowe, wyznaczają styl i charakter życia, są nośnikami wielkiej ilości informacji, uczą, ale przede wszystkim zmieniają zachowania. Inwazyjny charakter mediów dla współczesnej rodziny wymaga analizy wielu zagadnień, refleksji, zasad i wzorców zachowań rodziców. Dając dobry przykład świadomego, odpowiedzialnego i bezpiecznego funkcjonowania w świecie hybrydowym, należy przypominać dzieciom, że nierozważne zachowania w sieci mają poważne konsekwencje w życiu poza mediami. Nie każda osoba poznana w sieci, a podająca się za ich przyjaciela, ma uczciwe zamiary. Należy podchodzić bardzo krytycznie do informacji, które czerpane są z Internetu. Rodzice muszą uzmysłowić dziecku, że anonimowość w sieci jest tylko pozorna. Poruszając się po niej, pozostawiają wiele cyfrowych śladów, i to nie tylko celowo, ale najczęściej zupełnie nieświadomie. Rodzice powinni wiedzieć, że dziecko ma prawo 


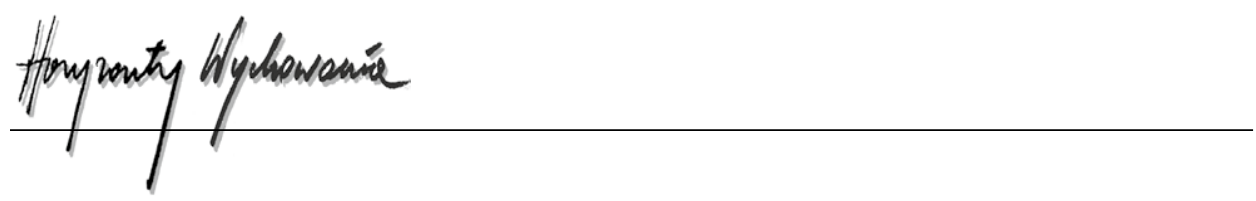

oczekiwać, zarówno z ich strony, jak i znajomych, szacunku wobec prywatności. Nikt nie ma prawa publikować zdjęć z udziałem dziecka bez jego zgody. Nie tylko dzieci, ale i rodzice powinni sobie uzmysłowić, że wrzucając informację do sieci, dzielą się nią ze wszystkimi tubylcami cyfrowymi, tracąc nad nią kontrolę. Rodzice powinni uczyć dzieci szacunku i poszanowania opinii innych, tłumaczyć, że krzywda wyrządzona w sieci boli nie mniej niż ta wyrządzona w realnym świecie, podobnie jak utrata dobrej reputacji czy zaufania ze strony rodziny. Najważniejsze jednak jest wspólne określenie z dziećmi zasad bezpiecznego korzystania z Internetu, przypomnienie, że nie jest on wolny od zagrożeń. Podsumowując, zasadniczym problemem w budowaniu kultury rodziny w kontekście nowomedialnym „jest dbałość o zachowanie równowagi między techniką i kulturą, stanowiących niejako awers i rewers tej samej rzeczywistości, w której jesteśmy równocześnie zanurzeni” (Morbitzer, 2016, s. 66).

\section{BIBLIOGRAFIA}

Batorowska, H. (2009). Kultura informacyjna w perspektywie zmian w edukacji. Warszawa: Wydawnictwo SBP.

Cieciura, M. (2012). Wybrane problemy społeczne i zawodowe informatyki. Warszawa: OZE.

Dec, M., Dereń, A. i Grabek, M. (2014). Obraz współczesnej rodziny a konsumpcyjny styl życia. W: U. Gruca-Miąsik (red.), Rodzina - centrum świata. Rzeszów: Wydawnictwo Uniwersytetu Rzeszowskiego, 171-182.

Doniec, R. (2017). Oblicza dzieciństwa w domu polskim lat powojennych na przykładzie wspomnień. W: A. Ładyżyński i M. Piotrowska i M. Kasprzak (red.), Dom rodzinny w doświadczeniu (auto) biograficznym. Wrocław: Instytut Pedagogiki Uniwersytetu Wrocławskiego, 217-240.

Furmanek, W. (2012). Kultura informacyjna komponentem kultury pracy. Edukacja - Technika Informatyka, 3/2, 13-24.

Giddens, A. (2001). Nowoczesność i tożsamość. „Ja” $i$ społeczeństwo w epoce późnej nowoczesności. Tłum. A. Szulżycka. Warszawa: Wydawnictwo Naukowe PWN.

Goban, K. (2005). Cywilizacja medialna. Geneza. Ewolucja. Eksplozja. Warszawa: WSiP.

Gregorczyk, G. (2016). Znaczenie wzorca osobowościowego dorosłych w kształtowaniu postaw warunkujących twórcze i odpowiedzialne funkcjonowanie dzieci i młodzieży w społeczeństwie informacyjnym. W: H. Batorowska i Z. Kwiasowski (red.), Kultura informacyjna w ujęciu interdyscyplinarnym - teoria i praktyka. Kraków: Uniwersytet Pedagogiczny im. Komisji Edukacji Narodowej, Instytut Bezpieczeństwa i Edukacji Obywatelskiej, Katedra Kultury Informacyjnej i Zarządzania Informacją, 188-200.

https://archiwum.radiozet.pl/Wiadomosci/Swiat/Portugalia-matka-ogolila-corce-glowe-bo-smiala-sie-z-chorej-na-raka-00029403) (dostęp: 11.10.2019).

Kirwil, L. (2011). Polskie dzieci w Internecie. Zagrożenia i bezpieczeństwo - część 2. Częściowy raport z badań EU Kids Online II przeprowadzonych wśród dzieci w wieku 9-16 lat i ich rodziców. Warszawa: SWPS - EU Kids Online - PL.

Kwiasowki, Z. (2016). Znaczenie Internetu w wychowaniu. W: H. Batorowska i Z. Kwiasowski (red.), Kultura informacyjna w ujęciu interdyscyplinarnym - teoria i praktyka. Kraków: Uniwersytet Pedagogiczny im. Komisji Edukacji Narodowej, Instytut Bezpieczeństwa i Edukacji Obywatelskiej, Katedra Kultury Informacyjnej i Zarządzania Informacją, 176-187. 
Majak, K. (2013). Troll Parenting, czyli rodzice wyśmiewają własne dzieci w Internecie. Pozyskano z: http://natemat.pl/60525,trollparenting-czyli-rodzice-wysmiewaja-wlasne-dzieci-w-internecie (dostęp: 07.07.2018).

Maltz Bovy, P. (2013). The Ethical Implications of Parents Writing About Their Kids. The Atlantic. Pozyskano z: http://www.theatlantic.com/sexes/archive/2013/01/the-ethical-implications-of-parents-writingabout-their-kids/267170/ (dostęp: 15.11.2019).

Milewski, M. (2006). Nowe media a komunikacja interpersonalna: ujęcie społeczno-kulturowe. Studia Płockie, 34, 183-192.

Morbitzer, J. (2016). Współczesna przestrzeń obecności człowieka - między realnością a wirtualnością. Pedagogika, 13. Zeszyty Naukowe Wyższej Szkoły Humanitas, 59-68.

Morbitzer, J. (2017). O (braku) refleksji nas współczesnym światem mediów. W: W. Skrzydlewski (red.), Kultura - edukacja - technologia kształcenia. Konteksty nowomedialne. Poznań: Wydawnictwo Naukowe UAM, 89-104.

Ogonowska, A. (2015). Edukacja medialna jako forma profilaktyki uzależnień medialnych dzieci i młodzieży. Zarys problemu. W: A. Ogonowska i G. Ptaszek (red.), Edukacja medialna w dobie współczesnych zmian kulturowych, społecznych i technologicznych. Kraków: Wydawnictwo Impuls, 161-170.

Pomiankowska-Wronka, A. (2016). Rodzina w objęciach nowych mediów - Jak Internet wpływa na życie społeczne rodziny? W: K. Pujer (red.), Rodzina i szkoła wobec szans i zagrożeń społeczno-cywilizacyjnych. Wrocław: Exante, s. 55-65.

Postman, N. (1992). Technopoly: The Surrender of Culture to Technology. New York: Alfred a Knopf. Pruchnicka, J. (2012). Media Relations - promocja nauki i instytucji badawczych w mediach w Polsce i Europie. Marketing Instytucji Naukowych i Badawczych, 1(2), 165-183. Pozyskano z: http:// bazhum.muzhp.pl/media//files/ Marketing (dostęp: 19.11.2019).

Słysz, A. i Arcimowicz, B. (2009). Przyjaciele w Internecie. Gdańsk: Gdańskie Wydawnictwo Psychologiczne.

Sobczak, K. (2014). Tożsamość czy tożsamości? JA w świecie cyberrealnym. W: Z. Rykiel i J. Kinal (red.), Wirtualność jako realność. Rzeszów: Wydawnictwo Uniwersytetu Rzeszowskiego, s. 23-42.

Steinberg, S.B. (2017). Sharenting: Children's Privacy in the Age of Social Media. Emory Law Journal, 839(66), 839-884.

Tapscott, D. (2010). Cyfrowa dorosłość. Jak pokolenie sieci zmienia nasz świat. Tłum. P. Cypryański. Warszawa: WAiP.

Wallace, P. (2001). Psychologia Internetu. Poznań: Dom Wydawniczy Rebis.

Waluś, S. (2016). Współczesna rodzina wobec nowoczesnych technologii. W: K. Pujer, (red.), Rodzina i szkoła wobec szans i zagrożeń społeczno-cywilizacyjnych. Wrocław: Exante, 43-51.

Waluś, S. (2019). Środki masowego przekazu w nowoczesnym świecie - szanse i zagrożenia dla współczesnej rodziny. W: V. Tanaś i W. Welskop (red.), Mass media we współczesnym świecie. Łódź: Wydawnictwo Naukowe Wyższej Szkoły Biznesu i Nauk o Zdrowiu, 143-151.

\section{Copyright and License}

This article is published under the terms of the Creative Commons Attribution - NoDerivs (CC BY- ND 4.0) License http://creativecommons.org/licenses/by-nd/4.0/ 